\title{
Performance, the Arts, and Curricular Change
}

\author{
Sharada Gade
}

\begin{abstract}
The need to improvise and take action as a practitioner draws on Schwab's notion of deliberation and the Greek concept of poiesis. Inspired by an impromptu discussion with students at a computer summer camp, the author uses the works of Sarason, Eisner, and Stenhouse to show how practitioner performance, student audience, educational inquiry, teacher as researcher, and curricular change are interrelated.
\end{abstract}

\section{Background}

This article examines the many actions taken by practitioners and the meaning their actions have in the classroom. In particular, I consider the deliberation of actions, as described by Joseph Schwab (1970):

Deliberation is complex and arduous. It treats both ends and means and must treat them as mutually determining one another. It must try to identify, with respect to both, what facts may be relevant. It must try to ascertain the relevant facts in the concrete case. It must try to identify the desiderata in the case. It must generate alternative solutions. It must make every effort to trace the branching pathways of consequences which may flow from each alternative and affect desiderata. It must then weigh alternatives and their costs and consequences against one another, and choose, not the right alternative, for there is no such thing, but the best one. (p. 618)

Schwab not only recognizes the need for practitioners to consider both ends and means when taking action, but also the importance of choosing alternatives that best achieve desirable outcomes. To fully understand the meaning that such actions convey, I turn to the Greek notion of poiesis, which draws attention to what is achieved in the completion of any action. Unlike praxis or doing, which conveys meaning in its satisfactory conduct, poiesis is the making or production of meaning, subsisting in the work that is left behind once actions have been taken. Nicholas Lobkowicz (1977) explains,

Praxis or doing is that human mode of conduct that contains its meaning in itself and whose completion therefore consists of its satisfactory accomplishment. The constantly recurring Greek example is flute playing, but all ethical and political actions are interpreted according to this model. Poiesis, or making, by contrast is production: its completion and meaning subsist in the work that it leaves behind. He who builds a ship or attempts to cure a sick man has ultimately achieved nothing as long as the ship is not finished or health is not restored. By contrast, he who acts as a responsible member of the polis never finishes, because every political action entails others, but he can at each instant be at his goal, which is to act as a good man. The authentic political action, as the Greeks understand it, is not something like a path or step to completion but a part of the completion itself. (p. 18)

Lobkowicz identifies actions taken by practitioners with poiesis, whose significance lies in helping them attain greater good in their taking and completing every step. My own attention to poiesis came about 
while reflecting on the transformative nature of efforts practitioners take while conducting classroom interventions (Gade, 2016a). I became aware of Schwab's notion of deliberation while teaching a curriculum studies course to postgraduate students. This further allowed me to draw on the works of Seymour Sarason, Elliot Eisner, and Lawrence Stenhouse, whose contributions are explored in this article.

\section{Improvisation at the Summer Camp}

Organized by a colleague at my university, the 60 middle school students I met at their summer camp were selected from different district schools in the Indian state of Telangana. The camp was held next to a training centre in the capital Hyderabad; it had audiovisual and other facilities that were lacking in most government schools. In this weeklong residential camp for girls and boys, the students were familiar with computer-based instructional modules in various subjects. My colleague asked me to talk to students about widespread social issues and create a PowerPoint presentation to help guide the discussion. I was also asked to speak in English with students whose mother tongues were most likely the Indian languages of Telugu or Hindi. This activity took two hours and was held at the beginning of the school day at 9 a.m. As a former teacher and now researcher, I decided to use my extensive collection of photographs downloaded from the National Geographic website to help mediate discussion about the many commonalities in our lives. The images depicted were diverse: a woman from the Ladakh area dressed in traditional attire; a Vietnamese fisherman catching crabs at dawn; a Hakka house in China; and an Indian villager squatting on a roadside pavement. I asked the students to work in small groups and share their thoughts about these various scenes. Next, I asked the whole group the following question: "What is the nature of our world and what makes us human?"

While this activity proved to be successful, I had a great deal of trepidation at the outset and asked myself many questions: "How should I start off my session after being introduced to the students? What should I do first to allow my students and I to fill the two hours with teaching and learning?" I knew that my years of teaching could come into play while reading the subtext of a student's query or facilitating a larger group conversation. I prepared slides to guide the discussion, but the question still remained: "How was I to actually start?" It is with these thoughts that I walked into the classroom that summer morning, greeted students after being introduced to them by my colleague, and asked if I could speak in English. I also mentioned that I could speak in Hindi and Telugu if needed-a declaration that helped the students and I share some common ground. I then mentioned that we would discuss some pictures I had brought for them. On the spur of the moment, I told the students that the languages we spoke everyday borrowed words from other languages. For example, just as bat and ball had become part of the south Indian language of Telugu, words with Indian roots like curry, shampoo, and bungalow had also become part of the English language. The discussion then took an unexpected turn. I asked the students if they were aware that the Indian word chuddies (i.e. underpants) had recently been added to the Oxford English Dictionary. Being on the verge of adolescence, most students kept a straight face when I my mentioned chuddies. A few squirmed in their seats, not wanting to appear embarrassed about discussing undergarments, away from the privacy of their homes. I'm sure many of them were asking themselves: "What was this teacher talking about? What might she do next?" At any event, my impromptu discussion 
about chuddies definitely captured the students' attention. We then moved on to watching and discussing my selection of photographs. In retrospect, I savoured my improvisation, my spur-of-the-moment diversion in our conversation to the English lexicon. It was a performance that broke the ice, allowing me to interact successfully with the students. I had certainly not planned for these actions, yet my coming across a related newspaper item recently led my thoughts in this direction. My actions were not only deliberative in my choosing to draw the attention of students to the English language we spoke, but they also exhibited poiesis in bringing about a sharper focus on the greater truth that all languages borrow words from one another. As practitioners, each of us perform many such actions in our own teaching, tailored to the contexts we routinely orchestrate. My mention of chuddies in this paper also stands for practitioner actions and performances more generally, whose efficacy in productive learning environments is something I intend to examine.

\section{Teaching as a Performing Art: Seymour Sarason}

Based on his study of American schools in the 1970s, Seymour Sarason (1990) makes two insightful observations about educational reform: that conditions for learning in schools that exist for students must also be made available for teachers, and that students must be helped to negotiate the growing gulf between what is learnt in school and the world outside (Gade, 2016b). I view my ability to use photographs for my students as an outcome of the very freedom I was given as practitioner. My alluding to the English lexicon was also an opportunity for them to bridge the English they were learning at school to its contemporary growth outside. In Teaching as a Performing Art, Sarason (1990) makes three assertions that resonate with my present study - the first of which concerns the character of a performing artist.

A performing artist is one who uses him or herself to convey an emotion, or situation, or imagery intended to be meaningful and stimulating to an audience. The "message," whatever the medium, is for the purpose of evoking in others the response "I understand and believe what I am seeing and believing. You have not left me cold, you have engaged me." It is an engagement that leads symbolically (and hopefully) to a marriage: artists and audiences are willingly in a new, reciprocal relationship. In the case of the teacher, engagement is a sustained one; it is not a onenight stand. (p. 6)

Sarason draws attention to many significant aspects, beginning with how performing artists are themselves the source of the emotion or imagery they intend to convey. Finding out that chuddies had been added to the Oxford English Dictionary motivated me to connect in a similar way with my students. Next is the reciprocal relationship performing artists are able to achieve, so that audiences relate to and believe what practitioners say. It is possible that alluding to the use of common words like bat and ball in Telugu helped my students and I in this direction. Finally, as all practitioners will recognize, my performance that morning had resulted from my ongoing commitment to teaching over the years. Equally noteworthy is Sarason's (1990) second assertion, which examines the audience of a performing artist. 
Audiences are silent performers. They are silent but not passive, at least they did not come expecting to be inwardly passive. They come expecting to see themselves and a slice of life differently. They do not expect to be bored, unmoved and sorry they came. They come to be transported, not to remain their accustomed selves. Audiences expect actors to be their roles, however different that "being" is from their everyday being. To the extent the performer can engender that illusion in the audience, the artist has discharged his or her obligation to the audience. (p. 14)

Far from being passive performers, audiences come to expect an experience that will set their sights higher and enable them to develop a fresh perspective on what may have previously known with certainty, like words in a lexicon. The dialectic between audiences and performers is a relationship inadequately treated in teacher preparation programs. Not sufficiently theorized and understood, the dynamics of this very dialectic is also learnt at great personal cost when practitioners start teaching. Sarason's third assertion is taken verbatim from Arthur Jersild's work When Teachers Face Themselves.

The teacher's understanding and acceptance of himself is the most important requirement in any effort he makes to help students to know themselves and to gain healthy attitudes of selfacceptance. ... Such an endeavour means an effort to overcome the prevailing tendency in education to encourage the learner to understand everything except himself. ... It means an effort to achieve a better integration of thinking and feeling on the part of both children and adults. (Jersild, 1955, as found in Sarason, 1999, pp. 52-53)

In addition to highlighting how performing artists draw on individual selves to inspire an audience, the above passage calls attention to a vital characteristic of education-that the enterprise of education has erroneously come to expect learners to understand everything except their own selves. It is possible that my mention of chuddies, and the resultant discomfort some students showed that morning, sensitized them to the intimate nature of words. Such an instance exemplifies Sarason's attention to the need of striking a balance between feeling and thinking or emotion and cognition in teaching and learning.

\section{Arts-Based Inquiry: Elliot Eisner}

Eisner has long held a mirror to mainstream views in education-which are influenced by a positivist philosophy of science-and finds arts-based inquiry to complement such views in an insightful manner. Eisner points out that artistic forms of expression, including performances, cannot be strictly codified, and are valid in educational contexts to the extent that they inform audiences. Focused on human experiences, artistic approaches are also flexible, enabling practitioners to adopt diverse approaches in communicating with their audiences. Eisner (1981) thus advocates arts-based educational inquiry,

Artistic approaches to research are less concerned with the discovery of truth than with the creation of meaning. What art seeks is not the discovery of the laws of nature about which true statements, or explanations can be given, but rather the creation of images that people will find meaningful and from which their fallible and tentative views of the world can be altered, rejected, or made more secure. Truth implies singularity and monopoly. Meaning implies relativism and diversity. Truth is more closely wedded to consistency and logic, meaning to diverse interpretation and coherence. Each approach to the study of educational situations has its own unique perspective to provide. Each sheds its own unique light on the situations that humans seek to understand. (p. 9) 
Aligning personally governed meaning and significance with an abiding search for the truth, Eisner takes into account the social and human diversity of our everyday lives. In the passage below, he discusses the difference between the "craftsman in the classroom" and the "artist in the classroom."

The craftsman in the classroom has the repertoire, is skilled in its use, and manages the performance quite well indeed. But the craftsman creates essentially nothing new as a performer. This person's mark is known by the skill with which he or she uses known routines. ... The artist in the classroom invents new ones in the process. Such modes of performance are not plentiful, and they require ingenuity and all of the skill that the person possesses. The artist is rarer than the craftsperson. (Eisner, 1983, p. 11).

In the context of the summer camp discussed earlier, using photographs as educational resources can be considered an act of "craftmanship," while my improvisation in discussing chuddies to establish a rapport with the students can be viewed as a type of "performance" or "artistry." Two clarifications are helpful here: First, by the "arts," Eisner does not limit himself to visual arts, music, or dance in making the above distinction. Second, he does not view practitioner performances by artists as something routine. In fact, Eisner deems those improvisational acts to be artistic insofar as teachers derive aesthetic satisfaction from them. Highlighting the aesthetic nature of rewards associated with such acts, Eisner (1983) elaborates,

The aesthetic in teaching is the experience secured from being able to put your own signature on your own work - to look at it and say it was good. It comes from the contagion of excited students discovering the power of a new idea, the satisfaction of a new skill, or the dilemma of an intellectual paradox that once discovered creates. It means being swept up in the task of masking something beautiful - and teachers do make their own spaces and places. They provide, perhaps more than they realise, much of the score their students will experience. (p. 12)

Speaking to practitioners who enjoy what they do-and whose students are swept away by the beauty of the moment-Eisner reiterates the manner in which practitioners derive aesthetic satisfaction. I too shared in this satisfaction as an instructor at that summer camp, leaving an indelible imprint on students' ubiquitous use of words. In contrast with a rule-governed approach that could be personally stifling to both me and my students, I consider my improvisation to be deliberative, display poiesis, and draw also on my inner self. Indeed, Eisner declares artistry to be the very apotheosis of any performance, one that can be observed and shared within any community. Understandably, these actions are carried out in varying degrees in diverse educational contexts as well.

\section{Teacher as Artist Is Researcher: Lawrence Stenhouse}

Stenhouse (1988) considers teaching to be an art, an exercise of skill expressive of meaning. He believes the form in which this meaning is expressed allows learners to understand what is being taught and/or learned.

All good art is an inquiry and an experiment. It is by virtue of being an artist that the teacher is a researcher. ... The artist is the researcher par excellence ... engaged in inquiry, in research and development ... And this development, though it involves improvement of technique, is not for the sake of technique. It is for the sake of the expression of a truth in a performance which challenges criticism in those terms. (p. 47) 
Elaborating upon Eisner's position that artistic activities are those in which practitioners derive aesthetic satisfaction, Stenhouse considers art to involve experiment and inquiry-by virtue of which teachers as artists are researchers. Based on his extensive work with teachers, he asserts that curricular reform efforts must emphasize the teacher's development as an artist-thus also recognizing the role of teacher as a researcher. A proponent of teacher collectives to both express solidarity and derive political power, Stenhouse (1988) views in-service professional development as one in which experienced teachers can work on their own art. He views any teacher training to effect change to be a nonstarter, since teachers are primarily the ones who need to become artists, conduct research, and/or initiate change,

As a starting point teachers must want change, rather than others wanting to change them. That means that the option of professional development leading toward professional satisfaction of a kind that brings an enhancement of self must be made clear and open to teachers. Teachers have been taught that teaching is instrumental. When we say that teaching is an art, we are saying that the craft of teaching is inseparable from the understanding taught. In short, teaching is intrinsic. (p. 50)

Agreeing with Eisner's view on aesthetic satisfaction and Jersild and Sarason's need for self-reliance, Stenhouse wants teachers to recognize the central role they play in achieving curricular reform. Moreover, Stenhouse (1988) asserts below that there is "no absolute and unperformed knowledge."

The artist is the researcher whose inquiry expresses itself in performance of his or her art rather than (or as well as) in a research report. In an essentially practical art, like education, all the research and all the in-service education we offer should support that research toward performance on the part of the teacher. For there is in education no absolute and unperformed knowledge. In educational research and scholarship the ivory towers where the truth is neglected are so many theatres without players, galleries without pictures, music without musicians. Educational knowledge exists in, and is verified or falsified in, its performance. (p. 51)

Stenhouse here helps to bring my discussion—which began with performers and audiences—full circle. He posits that any educational knowledge both exists and can be verified or falsified only in its performance. Similarly, I view the act of drawing my students' attention to the way living languages borrow from contemporary usage, to be held up to the same performative scrutiny. In addition to knowing bat and ball in Telugu, or shampoo and bungalow in English, my students might also understand the use of the expression chuddy buddy (i.e. when referring to a friend from one's early childhood, played with while dressed up in informal clothing). Equally important is Stenhouse's view that educational research cannot solely be the domain of ivory towers and must bear the quality of being viable for performance in day-to-day practice. Underlying Stenhouse's stance on the performative viability of research is his premise that teachers as artists are researchers who derive intrinsic satisfaction from curricular change. A nuanced meaning thus underlies Stenhouse's (1975) famous declaration: "It is teachers who, in the end, will change the world of the school by understanding it" (p. 208). 


\section{Conclusion}

In terms of theory and practice, my research praxis led me to formulate my objective and tool in dialectical unity in this study and address ontological issues in an epistemological manner (Gade, 2017). The insightful work of Sarason, Eisner, and Stenhouse showed how diverse aspects such as practitioner self, student audiences, arts-based inquiry, teacher as artist becoming researcher, and curricular change were interrelated.

I thus came to examine the nature of the deliberation I exercised as a practitioner with new students at a summer camp. In drawing their attention to words being added to the English lexicon, I brought to fruition a dialectic that lay between the means and ends available to me. As recognized by Schwab, there was no right way to carry out this task. If I were to work with a smaller group of students or with those in their own school premises, I would have achieved my goal quite differently, starting anew. However, my ability to capture the students' interest that summer morning made the pedagogical moment come alive and produce something from seemingly nothing. Exemplifying the Greek notion of poiesis, I was able to aim for the greater good in its very completion, something practitioners carry out quite routinely in their own teaching.

Next, the works of Sarason, Eisner, and Stenhouse enabled me to theoretically reflect on practitioner performance. Sarason spoke of a believability that accounts for how student audiences willingly participate in their learning. Equal importance was also placed on their disposition as an audience, geared to see the world around them in a better light. Eisner next identified those educational acts-in which practitioners derive aesthetic satisfaction—as artistic. Fraught with intellectual risk taking, these attempts have the potential to create newer spaces for teacher and student learning in schools. Moreover, such attempts characterize scientific research according to Stenhouse, whose notion of inquiry is grounded in the kind of change practitioners themselves seek. The rewards for such attempts are not only intrinsic, but also ratified in public performances alone. This is why Stenhouse sought teacher collectives to both gain solidarity and bring forth each other's performances as inquiries for wider discussion. Sarason speaks of teacher performance in alluding to performing artists, while Stenhouse uses the term in relation to teachers bringing about curricular change. These two perspectives are not in opposition. Rather, they are enriched by Eisner's attention to the aesthetic satisfaction practitioners derive in orchestrating their own performances-whose grasp now seems less mysterious and more nuanced in terms of the interconnections identified in this study. 


\section{References}

Eisner, E. (1981). On the differences between scientific and artistic approaches to qualitative research. Educational Researcher, 10(4), 5-9.

Eisner, E. (1983). The art and craft of teaching. Educational Leadership, 40(4), 4-13.

Gade, S. (2016a). Oneself in practitioner research, with Vygotsky and Bakhtin. Reflective Practice, 17(4), 403-414.

Gade, S. (2016b). School change and educational reform: How activity theory could respond to Sarason's insights. Da Investigação às Práticas, 6(2), 25-38.

Gade, S. (2017). Research as praxis, en route theory/practice teacher-researcher collaboration: A self-study. Nordic Studies in Mathematics Education, 22(3), 5-23.

Jersild, A. (1955). When teachers face themselves. Teachers College Press.

Lobkowicz, N. (1977). On the history of theory and praxis. In T. Ball (Ed.), Political theory and praxis: New perspectives (pp. 13-27). University of Minnesota Press.

Sarason, S. (1990). The predictable failure of educational reform: Can we change the course before it's too late. Jossey-Bass Publishers.

Sarason, S. (1999). Teaching as a performing art. Teachers College Press.

Schwab, J. J. (1970/2013). The practical: A language for curriculum. Journal of Curriculum Studies, 45(5), 591-621.

Stenhouse, L. (1975). An introduction to curriculum research and development. Heinemann.

Stenhouse, L. (1988). Artistry and teaching: The teacher as focus of research and development. Journal of Curriculum and Supervision, 4(1), 43-51.

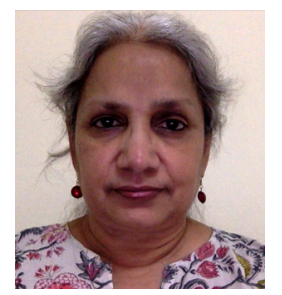

Sharada Gade is an independent researcher in Hyderabad, India, where she was a middle school classroom teacher for over a decade. Following doctoral work in Norway, she has held postdoctoral fellowships in India, Sweden, the United States, and the United Kingdom. Her ongoing research focuses on mathematics education, cultural-historical activity theory perspectives, practitioner research, and classroombased curriculum studies. Sharada is also a Visiting Faculty at the Tata Institute of Social Sciences, Hyderabad. She is currently writing a book about working collaboratively with teachers to help them take transformative action in their classrooms. 